\title{
A (DE) HUMANISING PEDAGOGY: LET THE TEACHERS SPEAK
}

\author{
Leila Kajee \\ Faculty of Education, University of Johannesburg (South Africa)
}

\begin{abstract}
Given the nature of South Africa's linguistically and culturally diverse classrooms, it is inevitable that teaching and learning from a social justice perspective be prioritised to address injustices and inequities. Paulo Freire (1970), who laments the state of dehumanization in education argues "the only effective instrument in the process of re-humanization is humanizing pedagogy." In this case study I draw on conversations with teachers in which I explore their understandings of a humanising pedagogy to answer questions 'What does a humanizing pedagogy encompass? What does it require of us in the context of teaching and learning environments?' I conclude that a humanizing pedagogy is crucial for both teacher and student success and critical for the academic and social resilience of students. The work emanates from a project between universities in South Africa and Brazil.
\end{abstract}

Keywords: Social justice, humanizing pedagogy, education.

\section{Introduction}

Given the nature of South Africa's linguistically and culturally diverse classrooms, it is inevitable that teaching and learning from a social justice perspective be prioritised to address injustices and inequities. While narrowly perceived to be 'just good teaching', deconstructions of justice become crucial. Essentially, social justice refers to fair and just relations between individuals and society; it involves breaking barriers for social mobility; breaking the cycles of oppression; and examining systems of power and privilege. Defined by Bell (1997: 3-4) as "full and equal participation of all groups in a society that is mutually shaped to meet their need. the process of social justice should be democratic and participatory, inclusive and affirming of human agency and human capacities for working collaboratively to create change." Inclusivity, participation, and equity are foregrounded as core concepts. Nieto (2006: 2 ) adds that social justice "challenges, confronts, and disrupts misconceptions, untruths, and stereotypes". To address injustice, we have to challenge and disrupt. Yet despite attempts to transition to a more inclusive, socially just order, legacies of disempowerment and dehumanisation continue to persist in society worldwide (Delport, 2016). And as Zinn and Rogers (2012: 76) say, "the educational arena remains a battlefront, in which the struggle to build voice, agency and community continues." One way of addressing these concerns is through a humanizing pedagogy.

In this paper, I examine the role of a humanising pedagogy and implications the concept has for education. I adopt a qualitative case study to examine teachers' shared understandings of a humanising pedagogy in their teaching-learning contexts.

\section{Theoretical framing: Humanising pedagogy}

Humanising pedagogy grew out of Freire's (1970) critical pedagogy, and may be considered a method of instruction that "ceases to be an instrument by which teachers can manipulate students, but rather expresses the consciousness of students themselves" (Freire 1970: 51). Freire argued that humanizing teachers engage in a quest for mutual humanization, where students are co-investigators in dialogue with teachers. A dialogic approach develops critical consciousness, and teachers who engage in humanizing pedagogy engage in praxis, reflection, and action upon the world to transform it. Freire laments the state of dehumanization in education and asserts that "the only effective instrument in the process of re-humanization is humanizing pedagogy." For Bartolomé (1996) a humanizing pedagogy promotes respect, trusting relationships between teachers and students, academic rigor and learning contexts where power is shared by teachers and students. Macedo and Bartolomé (2000) add that the pedagogy values students' background knowledge, language, culture, life experiences. 
Bartolomé (1994) argues for a humanizing pedagogy that respects and uses reality, history and perspectives of students as an integral part of educational practice. He argues that teachers who work with subordinated students in particular have a responsibility to assist them in appropriating knowledge bases and discourse styles seen as desirable in society. This process must be additive. A humanizing pedagogy is crucial for both teacher and student success and critical for the academic and social resiliency of students, given that educational policy is dominated by standardized and technical approaches to schooling that dehumanize students, especially those of colour (Salazar 2013). Freire's conceptualization of "humanization," "pedagogy," and "humanizing pedagogy" is therefore seen as a counter-practice to dehumanization in education.

In Huerta's (2011: 49) work with Latino children, she explains that teachers who employ humanizing pedagogy in the classroom understand that learning is an act of linking new information to prior knowledge in and out of school, and that learning occurs in a social cultural context. We must understand that language is a tool for learning and through a culturally bound, socially mediated process of language development, children construct mental frameworks (schema) for perceiving the world around them. Teachers who engage in humanizing pedagogy engage in classroom practices that respect cultural differences and reflect care for students. They critically question their deficit views of subordinated students and recognize students as knowers and participants in their learning. They take action to create pedagogical structures that help to balance asymetrical power relations in society.

\section{The study}

This work emanates from collaboration between universities in Brazil and South Africa. The focus of the project is teacher engagement with education for social change, social justice, cohesion and peace in the two countries. This work serves to report on one aspect in the South African leg of the project. Graduate students involved in the project participated in an introductory seminar where key concepts were deconstructed. The participants were eight students, who are also English teachers. Six are female, and two male, and all except for two are South African. The aim of the work was to examine their thoughts on what a humanizing pedagogy might entail. The work emanates from group discussions with the teachers. All participants also wrote narratives of (de)humanizing teaching-learning experiences that they may have encountered. This paper reports on the group discussions.

\subsection{Discussion}

I highlight extracts from the discussions, then proceed to discuss them in relation to teachers' understandings of what a humanising pedagogy embraces:

Jana: "It is about being human, what does it mean to be human....it is about free will... It is about justice. We are equal in all that we do, colour should not separate us, blood brings us together, humanises us. A humanising teacher treats everyone alike. We have the same blood. That's why Schweize Reneke is important, we cannot separate children, they must be taught together"

Avi: "We all have a story, some stories are better than others. We have a history. We do not come from nowhere. Teachers must know who their students are. A humanising pedagogy acknowledges everyone's story. This is important in the South African context, given our history and our diversity. Be the revolution, get to the heart of the learner"

Marina: "Everyone speaks a different language. In our case (SA) we have 11 languages. I speak English, but as a teacher I have students who speak at least five different languages. A HP acknowledges the child's language, mother tongue. Yet English is the medium of instruction. I can speak about three languages, so I cannot speak to the learners in their languages, I use English which is our policy at school, at most schools. A humanising pedagogy will respect all languages. Yet how do we focus on this?"

Tsepo: "For me it is about culture. What is a person's culture? It is not race or religion, it is about values and beliefs. In my culture I am allowed multiple wives, but it is a patriarchal culture, this I will not support. Yet as a teacher I will respect all my learners' culture. It is their beliefs and how they were brought up. In school today cultural day is about dressing up in your traditional clothing...this is only a small aspect of culture, it is not what makes you, you...inside",

Vina: "A humanising pedagogy is like social justice, it would include bringing up discussions of a critical nature. We need to talk about SAs history, apartheid. And privilege. We have black and white kids in class. Yet white kids say they are not responsible for apartheid, their ancestors were. Yet they are privileged because of apartheid. We need to have these conversations at all levels."

India: "I spoke Afrikaans as a child, I still do. Many coloureds (mixed race) do. Yet now Afrikaans is stigmatised. It is called the boer language, and we must not speak it. I feel guilty now, yet I believe a humanising pedagogy recognises my Afrikaans heritage as it does other languages. I was not responsible for apartheid, I am a child of it. I am black, I speak Afrikaans. If this is not acknowledged it is dehumanising". 
South Africa is a country riddled with past and present inequities. As a fairly new 25 year old democracy, South Africa's past is tragically reflected in over 45 years of apartheid during which time black people did not have rights over where they lived, whom they married, or where and how they were educated. We lived under complete white domination. Decisions were made for us on the basis of skin colour and the texture of our hair. Since democracy, given the nature of the country's linguistically and culturally diverse classrooms, it is inevitable that teaching and learning from a social justice perspective be prioritised to address injustices and inequities. Three major themes emerged from the teacher group discussions, regarding their views on what a humanising pedagogy entails: justice, background stories and the value of language.

All the teachers referred to a sense of justice as being core to a humanising pedagogy. For Jana, skin colour is superficial, she considers blood a uniting force for human beings. For her a humanising pedagogy means that all learners must be treated the same. Jana makes an interesting reference to Schweize Reneke. Schweize Reneke is a little town in the North West of South Africa. The incident referred to occurred in January this year, when a Grade 1 teacher separated children into two language groups: one that spoke English and one that did not. These groups happened to consist of separate race groups as well, one black and one white. Her understanding was that the children would feel more comfortable among those who spoke their language. The incident went viral very quickly with much of the country referring to it as a racist act to divide children along linguistic grounds. The teacher later apologised, as her intentions were not racist. Vina too evokes social justice by calling for what he calls "discussions of a critical nature". Zembylas and others refers to these conversations as discomforting or troubling conversations. Vina's view that white children absolve themselves from apartheid is also troubling. He feels that a humanising pedagogy would involve us engaging in discomforting dialogues, where we get opportunities to acknowledge our privilege and entitlement, rather than engaging with 'apartheid denial'.

Avi understands a humanising pedagogy as acknowledging learners' backgrounds. Given the nature of diversity of learners' backgrounds, it is crucial that we listen to learners' stories or narratives. Storytelling lies at the heart of our experiences, they engage us at a spiritual level, and are the voice of change. Avi reminds us of this: that stories give voice to children. He also evokes us to "be the revolution". This is reminiscent of Freire's (1970) revolutionary teachers. Freire uses the term in opposition to "reactionary" teachers. For Freire (1970) revolutionary teachers establish a permanent relationship with students from subordinated cultures and languages. Revolutionary teachers practice a humanizing pedagogy where the method of instruction is not an instrument by which teachers can manipulate students, because it expresses students' consciousness (pg 51). Bartolomé (1994) too argues that a humanizing pedagogy values students' background knowledge, culture and life experiences, and creates learning contexts where power is shared by students and teachers (pg 248).

Schools need to do more than just teach students English. They must also strengthen cultural awareness and identity. Marina's focus on language and Tsepo's focus on culture foreground this. Marina's questioning of how to address language discrepancies in the classroom is a concern in South Africa. Given the linguistic and cultural diversity of South Africa, it is near impossible for teachers to be able to speak all the childrens' languages. However, it is important to acknowledge them. Too often, have children who speak languages other than English been considered marginal or deficit. Language must be highlighted as a vital element to humanisation. Childs (2016) explores the (potential) dehumanising nature of language use in many South African classrooms by highlighting the regular disconnect between the dominant language of the classroom and the home language of the learner. In contexts where English is hegemonic as the language of teaching and learning, Exploring the possibilities of translanguaging can bring about humanising experiences for learners as well as teachers. Childs (2016) says that translanguaging practices are inherently humanising, affording teachers and learners opportunities to participate as social, thinking, transforming individuals. Marina and India evoke these points. India's point however, refers to Afrikaans, originally emanating from Dutch colonisers, and spoken by Afrikaners and SA's coloured, or mixed race people (apartheid nomenclature used for clarity). Her view is that as a black person she should not feel guilty about speaking the language of the apartheid rulers, she has a right to the language.

Historical realities of dehumanizing in South African education have been well documented by researchers such as Alexander (2002), Chisholm (2004), Jansen (2009), and Soudien (2012). Zinn and Rogers (2012) add that the legacy of dehumanization has been wittingly and unwittingly absorbed into educational arenas that depict hierarchies of power, compliance, fear, suppression and loss of voice. Restoring voice and agency is a key characteristic of what it means to be human. Given our oral tradition, in the south, voice and storytelling are pertinent, storytelling, must be seen as a social and cultural activity. Loss of voice is one aspect of dehumanization; restoring voices equates with agency, which has implications for social justice and human pedagogies. 


\section{Conclusion}

For us to commit to increasing equity and excellence in education of culturally and linguistically diverse students, we must teach against the grain of dehumanizing practices (Salazar 2008). Relegating learners to the fringes of society through dehumanising policies and practices that reproduce social and academic inequities. For Huerta (2011) research in teacher education has placed emphasis on teacher knowledge and instruction, not enough on attitudes and perspectives that can contribute significantly to pedagogy. Teachers who embrace a humanizing pedagogy recognize the socio-historical and political context of their own lives and students' lives, including the influence of societal power, racial, ethnic identities and cultural values (Bartolomé; Freire 1970; Salazar and Fránquiz 2008). These teachers believe that marginalized students (due to race, economic class, culture) experience difference in how they learn, not in their ability to learn. Thus we need to listen to the voices of the classroom. We must let the teachers speak.

\section{References}

Alexander, N. (2002). Linguistic rights, language planning and democracy in post-apartheid South Africa. Language Policy: Lessons from Global Models. Monterey, CA.: Monterey Institute of International Studies.

Bartolomé, L. (1994). Beyond the methods fetish: Toward a humanizing pedagogy. Harvard Educational Review, 64(2), 173-195.

Bell, L.A. (1997) Theoretical foundations for social justice education. In M. Adams, L. Bell \& P. Griffith (Eds), Teaching for diversity and social justice: A sourcebook (pp. 3-15). New York: Teachers College Press.

Childs, M. (2016). Reflecting on translanguaging in multilingual classrooms: Harnessing the power of poetry and photography. Educational Research for Social Change vol. 5(1): 22-40.

Chisholm, L. (2004). Changing class: Education and social change in post-apartheid South Africa. Pretoria, HSRC Press.

Delport, A. (2016). Humanising Pedagogies for Social Change (Editorial) Educational Research for Social Change vol. 5(1): 6-9

Freire, P. (1970). Pedagogy of the oppressed (MB Ramos, Trans.). New York: Continuum, 2007.

Huerta, T.M. 2011. Humanising pedagogy: Beliefs and practices on the teaching of Latino children. Bilingual Research Journal 34: 38-57

Jansen, J. D. (2009). Knowledge in the blood: Confronting race and the apartheid past. Stanford, Stanford University Press.

Macedo, D., \& Bartolomé, L. (2000). Dancing with bigotry: Beyond the politics of tolerance. Educational Researcher, 30(6), 27-30.

Nieto, S. (2006). Solidarity, courage and heart: What teacher educators can learn from a new generation of teachers. Intercultural education, 17(5): 457-473.

Salazar del Carmen, M. (2013). A humanizing pedagogy: Reinventing the principles and practice of education as a journey toward liberation. Review of Research in Education, 37(1), 121-148.

Salazar del Carmen, M., \& Fránquiz, M. E. (2008). The transformation of Ms. Corazón: Creating humanizing spaces for Mexican immigrant students in secondary ESL classrooms. Multicultural Perspectives, 10(4), 185-191.

Soudien, C. (2012). Realising the dream: Unlearning the logic of race in the South African school. Pretoria: HSRC Press.

Zinn, D. and Rogers, C. (2012). A humanizing pedagogy: getting beneath the rhetoric. Perspectives in Education. Vol 30(4): 76-87. 